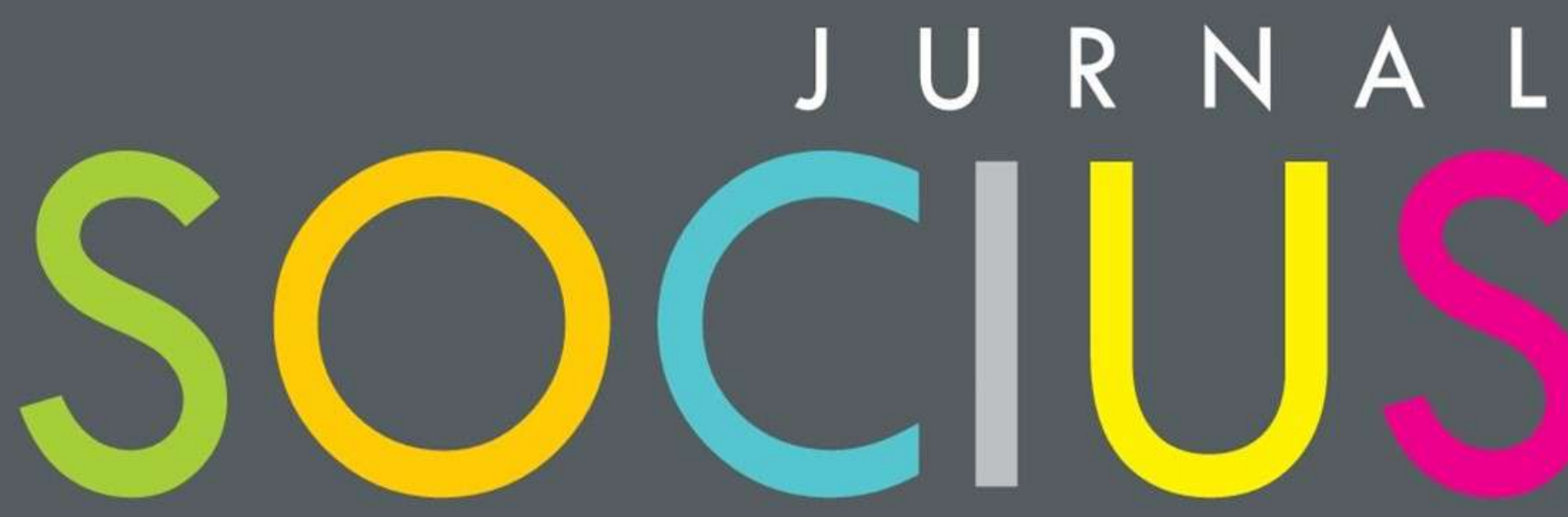

Journal of Sociology Research and Education

DITERBITKAN OLEH :

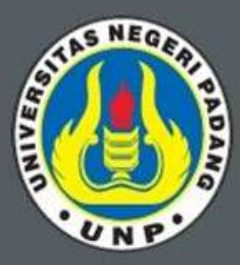

LABOR JURUSAN SOSIOLOGI FAKULTAS ILMU SOSIAL UNIVERSITAS NEGERI PADANG

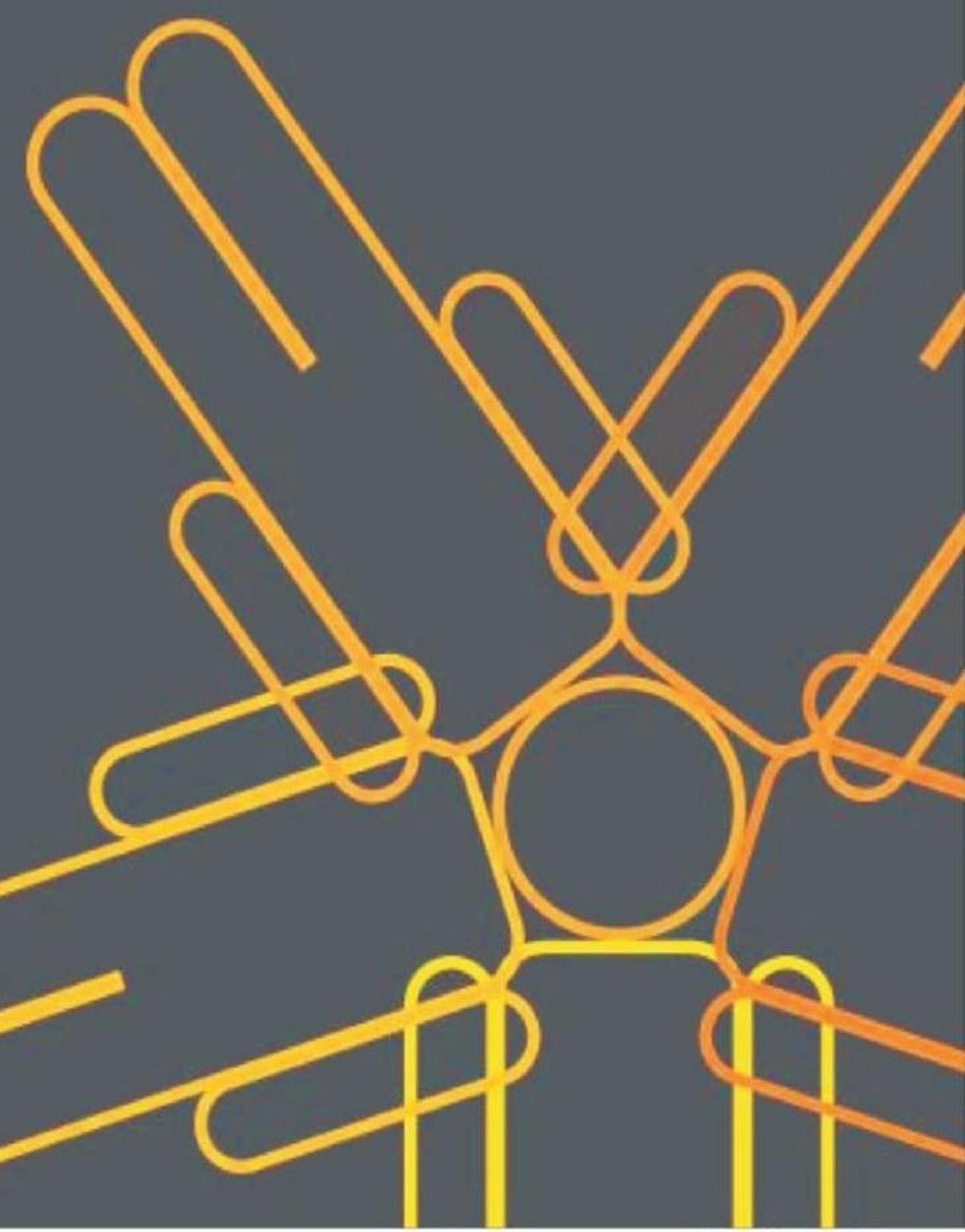




\section{SOCIUS}

Vol. 7, No. 1, Th. 2020

ISSN : 2356-4180 (cetak)

2442-8663 (online)

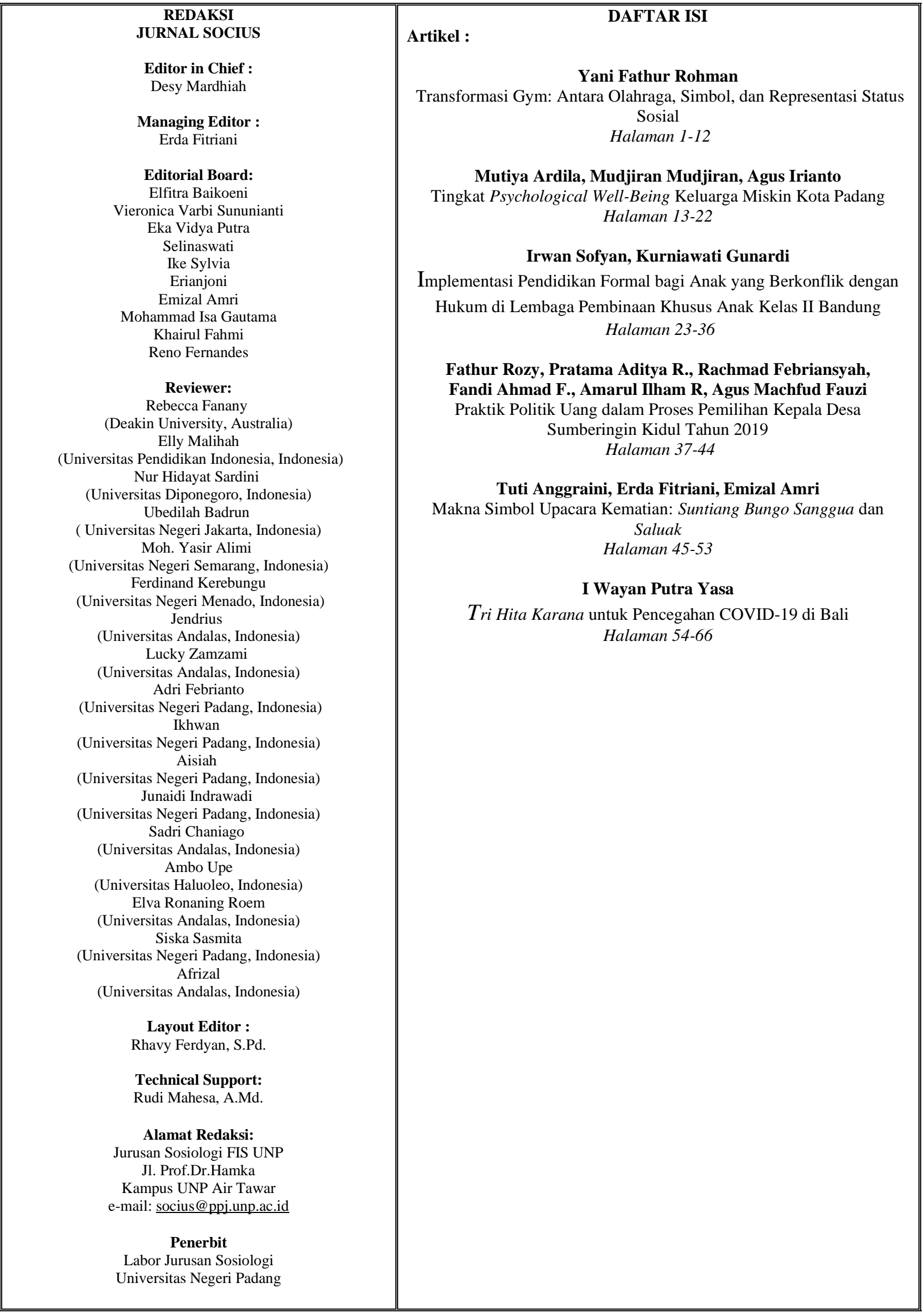




\title{
Tingkat Psychological Well-Being Keluarga Miskin Kota Padang
}

\author{
Mutiya Ardila ${ }^{1}$, Mudjiran Mudjiran ${ }^{2}$, Agus Irianto $^{3}$ \\ ${ }^{123}$ Universitas Negeri Padang
}

Email: mardilla89@gmail.com

\begin{abstract}
Abstrak
Tingginya angka kemiskinan akan memberikan dampak kepada kesejahteraan psikologis masyarakat terutama keluarga. Hal ini yang menjadi latar belakang dilakukannya penelitian. Jenis penelitian ini adalah kuantitatif menggunakan pendekatan deskriptif. Adapun populasi penelitian ini keluarga miskin yang tinggal di Kecamatan Nanggalo, Kota Padang, Provinsi Sumatera Barat. Teknik pengambilan sampel menggunakan cluster sampling. Instrumen yang digunakan adalah angket psychological well-being dan skala model Likert dengan tiga alternatif yaitu tinggi, sedang dan rendah. Teknik analisis data menggunakan statistik deskriptif. Berdasarkan hasil analisis data, dapat disimpulkan bahwa psychological well-being keluarga miskin Kota Padang 58,3\% berada pada kategori sedang, $35 \%$ berada pada kategori rendah dan 6,7\% berada pada kategori tinggi.
\end{abstract}

Kata kunci: Keluarga, Kemiskinan, Kota Padang, Psychological Well-Being

\begin{abstract}
The high poverty rate will impact the psychological well-being of people, especially families. This is the background of research. This research is quantitative by using a descriptive approach. The population in this study was poor families living in Nanggalo sub-district, Padang City, West Sumatra Province. The sampling technique uses cluster sampling. The instrument used was a psychological well-being questionnaire and a Likert scale model with three alternatives, namely high, medium and low. Data analysis techniques used descriptive statistics. The results got revealed that $58.3 \%$ of psychological well-being of poor families are in the moderate category, $35 \%$ are in the low category and the remaining $6.7 \%$ are in the high category.
\end{abstract}

Keywords: Family, Poverty, Padang City, Psychological Well-Being

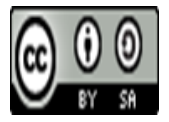

Received: March 19, $2020 \quad$ Revised: June 10, $2020 \quad$ Available Online: June 12, 2020

Jurnal Socius: Journal of Sociology Research and Education Vol. 7, No.1, Th. 2020

ISSN: Online 2442-8663 - Print 2356-4180 


\section{Pendahuluan}

Kemiskinan dipandang sebagai ketidakmampuan dari sisi ekonomi untuk memenuhi kebutuhan dasar makanan dan bukan makanan yang diukur dari sisi pengeluaran (Badan Pusat Statistik, 2019). Akibat dari tidak terpenuhinya kebutuhan tersebut mengakibatkan adanya kelaparan, tempat tinggal yang tidak layak, tidak mampu berobat jika sakit, tidak mampu untuk pergi ke sekolah dan tidak tahu cara membaca. Hal ini dapat mengakibatkan ancaman dan kerapuhan dalam menjalani kehidupan (Prawoto, 2009).

Kemiskinan masih menjadi momok yang menakutkan bagi negara berkembang ataupun negara maju dan merupakan salah satu masalah yang perlu diselesaikan secepatnya. Angka kemiskinan di Negara Indonesia masih tergolong tinggi. Berdasarkan data yang dilaporkan oleh Badan Pusat Statistik (2019), angka kemiskinan di Indonesia berada pada persentase $9,41 \%$. Hal ini dapat diartikan bahwa program pemerintah dalam mengatasi kemiskinan pada masyarakat belum berjalan optimal. Angka kemiskinan tertinggi berada pada Provinsi Papua dengan persentase 27,53\% dan angka kemiskinan terendah berada pada Provinsi DKI Jakarta dengan persentase $3,47 \%$. Wilayah Sumatera Barat berada peringkat 26 dengan persentase $6,42 \%$ (Badan Pusat Statistik, 2019). Sedangkan menurut Badan Pusat Statistik, (2019) angka kemiskinan di Kota Padang adalah 4,48\% dan untuk di Kecamatan Nanggalo terdapat sebanyak 192 keluarga yang berada pada garis kemiskinan.

Angka kemiskinan yang cukup tinggi akan berdampak pada masyarakat terutama keluarga. Jika suatu keluarga belum mampu memenuhi kebutuhan dasar tersebut maka keluarga itu dapat dikatakan keluarga prasejahtera atau keluarga miskin (Mudjiran, Hartati \& Rinaldi, 2017; Rochaida, 2016). Suatu keluarga dapat mengalami ancaman kerapuhan atau kerentanan berasal dari berbagai aspek, baik aspek sosial, ekonomi maupun lingkungan (Herien, 2012; Raharjo, Puspitawati \& Krisnatuti, 2015). Dampak dari semua gangguan ini tergantung dari seberapa besar ancaman yang ada. Pendapatan berpengaruh besar terhadap kebahagiaan individu, karena pendapatan memberikan kontribusi yang signifikan terhadap pemenuhan kebutuhan dasar, seperti makanan, sandang dan papan (Sugiharto, Hartoyo \& Muflikhat, 2016). Hal ini berarti, individu yang tidak mampu memenuhi kebutuhan dasarnya dan juga tidak memiliki kekayaan atau uang dan digolongkan dalam individu miskin akan memiliki kesejahteraan psikologis yang rendah dan berdampak pada psychological wellbeing individu tersebut (Hadjam \& Nasiruddin, 2003; Widyaningsih \& Muflikhati, 2015).

Psychological well-being adalah kondisi psikologis individu yang dapat menerima keadaan atau kondisi diri, baik dari sisi positif dan negatif serta dapat memaknai positif setiap kejadian atau peristiwa yang pernah dialami (Ryff \& Keyes, 1995). Psychological well-being (kesejahteraan psikologis) merupakan salah satu indikator kesejahteraan individu yang banyak digunakan untuk melihat pemenuhan individu terhadap kriteria fungsi psikologis positif (Hadjam \& Nasiruddin, 2003; Noviawati, Nuzulia, Marlina \& Undarwati, 2017). Individu yang memiliki psychological well-being yang baik ditandai dengan memiliki sikap positif terhadap diri sendiri, mempunyai hubungan yang baik dengan orang lain, dapat menentukan nasib sendiri dan mandiri, memiliki keterampilan dalam penguasaan lingkungan, memiliki tujuan hidup, serta berkembangnya kemampuan diri (Qoyyimah \& Wahini, 2017; Ward \& King, 2016). Sedangkan kondisi psychological well-being yang rendah dapat ditandai dengan merasa tidak puas akan diri sendiri, sulit membangun hubungan dengan orang lain, bergantung kepada orang lain, sulit mengelola lingkungan, tidak mempunyai tujuan hidup, dan tidak mampu mengembangkan pribadi atau stagnan (Qoyyimah \& Wahini, 2017). 
Hasil analisis wawancara yang dilakukan dengan pendamping PKH (Program Keluarga Harapan) kota Padang terkait psychological well-being diperoleh informasi bahwa pada umumnya keluarga miskin yang terdiri dari ibu-ibu penerima PKH masih cenderung tidak berani menyuarakan pendapat saat pertemuan kelompok bulanan berlangsung karena takut pendapat tersebut tidak disetujui oleh yang lainnya, kemudian seringkali tidak ingin mengikuti kegiatan yang ada di kelurahan dikarenakan ibu-ibu ini merasa lebih baik bekerja daripada mengikuti kegiatan tersebut. Selanjutnya berdasarkan hasil wawancara dengan ibu rumah tangga dari keluarga miskin Kota Padang diperoleh informasi bahwa pada umumnya bahwasanya Ibu dari keluarga miskin sering tidak mengikuti kegiatan yang dilakukan di sekitar kompleknya karena kesulitan menyesuaikan diri dengan lingkungan dan merasa tidak percaya diri saat berkumpul bersama. Hal ini mengakibatkan tidak terlalu banyaknya teman dan tidak adanya kegiatan baru yang diikuti. Lebih lanjut, dari hasil wawancara dengan Ibu AS (inisial) menunjukkan bahwa dirinya tidak mempunyai rencana masa depan untuk keluarganya terutama untuk anak-anaknya.

Berdasarkan uraian di atas, identifikasi masalah yang terjadi di lapangan adalah terdapat keluarga miskin yang kurang partisipasi dalam mengikuti kegiatan yang dilakukan di sekitar lingkungan, terdapat keluarga miskin yang kesulitan untuk menyesuaikan diri dengan lingkungan, terdapat keluarga miskin yang tidak percaya diri saat berkumpul dengan lingkungan di sekitar tempat tinggal, serta terdapat keluarga miskin yang tidak memiliki rencana akan masa depan anak. Lalu muncullah sebuah pertanyaan, bagaimana psychological well-being keluarga miskin di Kota Padang khususnya di Kecamatan Nanggalo? Berdasarkan pertanyaan penelitian tersebut, maka tujuan dari penelitian ini adalah untuk memperoleh dan mendeskripsikan data tentang psychological well-being keluarga miskin terkait dengan penerimaan diri, mempunyai hubungan yang baik dengan orang lain, dapat menentukan nasib sendiri dan mandiri, memiliki keterampilan dalam penguasaan lingkungan, memiliki tujuan hidup, serta berkembangnya kemampuan diri.

\section{Metode Penelitian}

Penelitian ini adalah penelitian kuantitatif dengan menggunakan pendekatan deskriptif. Penelitian deskriptif yaitu penelitian yang mendeskripsikan secara sistematis, aktual dan akurat mengenai fakta-fakta dan sifat populasi tertentu, atau mencoba menggambarkan fenomena secara detail (Yusuf, 2014). Populasi dalam penelitian ini adalah keluarga miskin di Kecamatan Nanggalo, Padang, Sumatera Barat yang berjumlah 192 keluarga. Teknik pengambilan sampel yang digunakan adalah cluster sampling. Sehingga sampel dalam penelitian ini berjumlah 60 keluarga miskin dari enam kelurahan yang ada di kecamatan Nanggalo. Instrumen dalam penelitian ini adalah angket yang berisi tentang pernyataan psychological well-being menggunakan skala model Likert dengan 3 allternatif pilihan yaitu tinggi, sedang dan rendah. Uji validitas instrumen menggunakan correlation product moment

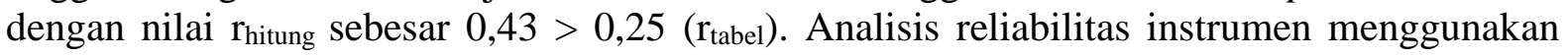
alpha cronbach dengan nilai sebesar 0,83. Teknik analisis data menggunakan statistik deskriptif yang bertujuan untuk mendeskripsikan psychological well-being keluarga miskin secara detail (Irianto, 2010). 
Mutiya Ardilla, Mudjiran Mudjiran, Agus Irianto Tingkat Psychological Well-Being Keluarga Miskin Kota Padang

\section{Hasil dan Pembahasan}

\section{Hasil}

Hasil data dari instrument diperoleh rata-rata skor 126,9 dengan persentase sebesar 77\%. Adapun nilai standar deviasi sebesar 11,3 dengan skor terendah sebesar 98 dan skor tertinggi sebesar 162. Lebih lanjut hasil data ini ditunjukkan pada Tabel 1.

Tabel 1. Psychological well-being keluarga miskin

\begin{tabular}{|c|c|c|c|c|}
\hline \multirow[t]{2}{*}{ Kategori } & \multicolumn{2}{|c|}{ Interval } & \multirow{2}{*}{$\begin{array}{c}\text { Frekuensi } \\
\text { (F) }\end{array}$} & \multirow{2}{*}{$\begin{array}{c}\text { Persentase } \\
(\%)\end{array}$} \\
\hline & Skor & $\%$ & & \\
\hline Tinggi & $>141$ & $>86$ & 4 & 6,7 \\
\hline Sedang & $\begin{array}{c}120- \\
141 \\
\end{array}$ & $74-86$ & 35 & 58,3 \\
\hline Rendah & $\leq 119$ & $\leq 73$ & 21 & 35 \\
\hline
\end{tabular}

Berdasarkan Tabel 1 menunjukkan bahwa sebanyak 4 keluarga miskin $(6,7 \%)$ memiliki psychological well-being yang berada pada kategori tinggi. Sebanyak 35 keluarga miskin $(58,3 \%)$ memiliki psychological well-being yang berada pada kategori sedang. Selebihnya sebanyak 21 Keluarga miskin (35\%) memiliki psychological well-being yang berada pada kategori rendah. Keluarga yang memiliki psychological well-being yang tinggi, memiliki karakteristik autonomy (kemandirian), environmental mastery (penguasaan lingkungan), personal growth (pertumbuhan pribadi), positive relations with others (hubungan positif dengan orang lain), purpose in life (tujuan hidup) serta self acceptance (penerimaan diri) yang tinggi sebaliknya, jika keluarga miskin memiliki psychological well-being yang rendah itu menandakan bahwa setiap aspek tersebut juga rendah (Sagone \& Caroli, 2014). Lebih lanjut analisis data berdasarkan indikator/aspek ditunjukkan pada Tabel 2.

Tabel 2. Psychological well-being keluarga miskin berdasarkan sub variabel

\begin{tabular}{llcccc}
\hline \multirow{2}{*}{ No } & Sub Variabel & \multicolumn{3}{c}{ Skor } \\
\cline { 3 - 5 } & Mean & SD & \% & Kategori \\
\hline 1 & Self Acceptance (Penerimaan diri) & 19,4 & 2,09 & 77,7 & Sedang \\
\hline 2 & $\begin{array}{l}\text { Positive Relations with Others (Hubungan } \\
\text { Positif dengan Orang lain) }\end{array}$ & 15 & 2,43 & 74,8 & Sedang \\
\hline 3 & $\begin{array}{l}\text { Environmental Mastery (Penguasaan } \\
\text { Lingkungan) }\end{array}$ & 23,2 & 2,58 & 77,3 & Sedang \\
\hline 4 & Purpose in life (Tujuan Hidup) & 29,8 & 4,78 & 74,6 & Sedang \\
\hline 5 & Personal Growth (Pengembangan Pribadi) & 24,3 & 2,76 & 80,8 & Sedang \\
\hline 6 & Autonomy (Kemandirian) & 15,2 & 2,4 & 76 & Sedang \\
\hline$\quad$ Keseluruhan & 126,9 & 11,3 & 76,9 & Sedang \\
\hline
\end{tabular}

Berdasarkan Tabel 2, secara keseluruhan psychological well-being keluarga miskin berada pada kategori sedang (76,9\%). Hal ini dapat dilihat pada kategori dari masing-masing sub variabel yaitu; Autonomy (Kemandirian) (76\%), Environmental Mastery (Penguasaan Lingkungan) (77,3\%), Personal Growth (Pertumbuhan Pribadi) (80,8\%), Positive Relations 
with Others (Hubungan Positif dengan Orang lain) (74,8\%), Purpose in life (Tujuan Hidup) $(74,6 \%)$ dan Self Acceptance (Penerimaan diri) $(77,7 \%)$ yang berada pada kategori sedang.

Selain melihat dari hasil analisis dari sub variabel, psychological well-being keluarga miskin juga dapat dilihat dari item angket yang memperoleh nilai rendah. Hasil analisis dapat dilihat pada Tabel 3 .

\section{Tabel 3. Item pernyataan yang berada pada kategori rendah}

\begin{tabular}{llcc}
\hline No & \multicolumn{1}{c}{ Pernyataan } & Skor (\%) & Kategori \\
\hline 1 & $\begin{array}{l}\text { Rasanya saya ingin memarahi orang yang menghina kondisi } \\
\text { ekonomi saya (item no. 1) }\end{array}$ & 66 & Rendah \\
\hline 2 & $\begin{array}{l}\text { Barang-barang yang saya beli sesuai dengan keinginan saya } \\
\text { (item no. 2) }\end{array}$ & 73 & Rendah \\
\hline 3 & $\begin{array}{l}\text { Saya kehabisan waktu mengerjakan semua pekerjaan rumah } \\
\text { tangga (item no. 6) }\end{array}$ & 69 & Rendah \\
\hline 4 & $\begin{array}{l}\text { Saya mengembangkan keterampilan yang diajarkan di } \\
\text { program keluarga harapan dengan menghasilkan produk- } \\
\text { produk yang bisa diperjual belikan (item no. 7) }\end{array}$ & 56 & Rendah \\
\hline 5 & $\begin{array}{l}\text { Menyenangkan bagi saya untuk mengikuti kegiatan di } \\
\text { program keluarga harapan karena bisa lepas dari rutinitas } \\
\text { bekerja di rumah (item no. 14) }\end{array}$ & 60 & Rendah \\
\hline 6 & $\begin{array}{l}\text { Saya memulai pembicaraan dengan orang yang belum saya } \\
\text { kenal sebelumnya (item no. 18) }\end{array}$ & 65 & Rendah \\
\hline 7 & $\begin{array}{l}\text { Menepati janji merupakan kewajiban bagi saya (item no. } \\
\text { 19) }\end{array}$ & 70 & Rendah \\
\hline 8 & $\begin{array}{l}\text { Saya akan keluar dari bantuan yang diberikan oleh } \\
\text { pemerintah (item no. 25) }\end{array}$ & 49 & Rendah \\
\hline 9 & Saya menabung untuk keperluan masa depan (item no. 27) & 60 & Rendah \\
\hline 10 & $\begin{array}{l}\text { Seandainya saya dulu disekolahkan, saya tidak akan hidup } \\
\text { dalam kemiskinan saat ini (item no. 33) }\end{array}$ & 62 \\
\hline
\end{tabular}

Tabel 3 menunjukkan bahwa terdapat 10 item instrumen psychological well-being yang berada pada kategori rendah. Hasil analisis Tabel 3 juga mewakili dari ke enam aspek yang diteliti. Hal ini dapat disimpulkan bahwa keluarga yang memiliki psychological well-being rendah dapat terlihat dari masing-masing aspek yang diteliti.

\section{Pembahasan}

Psychological well-being memiliki peranan yang penting bagi individu dalam menjalani kehidupan (Waters \& Fivush, 2015). Selain itu, psychological well-being juga memiliki dampak terhadap keluarga (Coley, Leventhal, Lynch \& Kull, 2013). Berdasarkan hasil analisis data pada Tabel 1, ditemukan bahwa sebanyak 21 keluarga miskin memiliki psychological well-being rendah. Kemudian sebanyak 35 keluarga miskin memiliki psychological well-being pada kategori sedang dan selebihnya berada pada kategori tinggi. Sesuai dengan hasil penelitian Hadjam \& Nasiruddin (2003); Islamia, Sunarti \& Hernawati (2019) yang menemukan bahwa psychological well-being keluarga miskin cenderung memiliki psychological well-being yang rendah. Hal ini bisa terjadi karena ketidakmampuan 
keluarga miskin dalam menerima setiap hal yang terjadi dalam keluarga dengan cara yang positif (Maifizar, 2016; Sudrajat, Sumpena \& Azis, 2017).

Meskipun secara keseluruhan psychological well-being keluarga miskin berada pada kategori sedang, tetapi keluarga yang memiliki psychological well-being rendah juga terbilang cukup banyak. Hal ini sebagai tanda bahwa sebuah keluarga yang berada pada taraf ekonomi yang rendah, memiliki psychological well-being yang rendah juga, sehingga sering mengakibatkan konflik di dalam keluarga (Balzarotti, Biassoni, Villani, Prunas \& Velotti, 2016). Karena keluarga yang memiliki psychological well-being rendah ditandai dengan ketidakmampuan untuk mandiri, kurang mampu untuk menguasai lingkungan, anggota keluarga kurang memiliki minat untuk mengembangkan diri, kurang memiliki hubungan yang positif dengan orang lain, kurang memiliki tujuan hidup, serta memiliki penerimaan yang rendah terhadap kondisi keluarga dan di sekitarnya (Dogan, Totan \& Sapmaz, 2013). Dengan kata lain, kesulitan ekonomi berdampak negatif terhadap perkembangan kognitif, behavioral, emosional dan perkembagan fisik anak dan remaja dalam keluarga yang mengalaminya dikarenakan tidak mampu memenuhi kebutuhan dasar. Kemiskinan dapat mempengaruhi segala lini kehidupan. Kemiskinan selalu menjadi faktor penghambat seseorang untuk mengaktualisasikan potensi diri dan membina hubungan yang dekat dengan orang lain untuk membangun dan mencari sumber daya yang baru di dalam kehidupannya.

Ada enam aspek penting dalam psychological well-being, termasuk autonomy (kemandirian), environmental mastery (penguasaan lingkungan), personal growth (pengembangan pribadi), positive relations with others (hubungan positif dengan orang lain), purpose in life (tujuan hidup) dan self acceptance (penerimaan diri) (Fadli, Alizamar, Afdal \& Ifdil, 2019). Selanjutnya, dari 33 item pernyataan dalam instrumen terdapat 10 item yang berada kategori rendah dan mewakili dari ke enam aspek yang diteliti (ditunjukkan pada Tabel 3). Untuk item pernyataan nomor 33, "Seandainya saya dulu disekolahkan, saya tidak akan hidup dalam kemiskinan saat ini" yang mewakili untuk aspek self acceptance (Penerimaan diri). Hal ini berarti bahwa ada penyesalan yang dialami oleh individu yang menyebabkan dirinya tidak dapat menerima kondisi saat ini dan selalu menyalahkan hal yang sudah terjadi di masa lampau. Hal ini berbanding terbalik dengan konsep self acceptance yang merupakan kondisi dimana individu dapat menerima segala kondisi pada diri dengan positif dan mampu menyadari segala sisi negatif yang ada pada diri. Bagi keluarga miskin, mampu menerima segala kondisi yang terjadi tanpa ada penyesalan serta tanpa membandingkan dengan kehidupan keluarga lain adalah salah satu cara untuk dapat meningkatkan psychological well-being (kesejahteraan psikologis) dalam menjalani kehidupan (Kuswardinah, Ansori \& Rosidah, 2014; Smith \& Silva, 2011).

Selanjutnya item pernyataan nomor 18 "Saya memulai pembicaraan dengan orang yang belum saya kenal sebelumnya" dan item pernyataan nomor 19 "Menepati janji merupakan kewajiban bagi saya " yang berada pada kategori rendah, mewakili aspek positive relations with others (hubungan positif dengan orang lain). Hal ini menandakan bahwa sebagian individu tidak mampu untuk menepati janji yang telah dibuat. Sehingga berdampak kepada hubungan individu tersebut dengan individu lain. Selain itu, kurangnya kemampuan komunikasi yang dimiliki menjadi penyebab banyaknya keluarga miskin terjebak dalam masalah. Permasalahan seperti itu bisa menjadi faktor penyebab rendahnya positive relations with others keluarga miskin terkait dengan psychological well-being (Hidalgo, Bravo, Martinez, Pretel, Postigo \& Rabadan, 2010). Menjalin hubungan yang positif akan sangat membantu suatu keluarga dalam mewujudkan kesejahteraan psikologis. Karena sejatinya, 
keluarga merupakan lingkungan sosial mikro yang juga membutuhkan untuk berhubungan dengan orang lain (Noviawati \& Narendri, 2017).

Item pernyataan nomor 6 "Saya kehabisan waktu mengerjakan semua pekerjaan rumah tangga dan item pernyataan nomor 7 "Saya mengembangkan keterampilan yang diajarkan di program keluarga harapan dengan menghasilkan produk-produk yang bisa diperjual belikan" yang mewakili aspek environmental mastery (penguasaan lingkungan). Environmental mastery (penguasaan lingkungan) merupakan kemampuan individu untuk memilih atau menciptakan lingkungan yang sesuai untuk kondisi dan kebutuhannya. Individu mampu mengontrol dan mengendalikan lingkungan yang kompleks, serta bertindak dan mengubah dunia sekitarnya melalui kegiatan mental dan fisik (Noviawati \& Undarwati, 2017). Analisis data penelitian menunjukkan bahwa environmental mastery (penguasaan lingkungan) berada pada kategori tinggi. Hal ini ditandai dengan kemampuan keluarga miskin dalam mengambil setiap keputusan yang tepat demi terjaganya kesejahteraan psikologis setiap anggota keluarga (Noviawati et al., 2017).

Selanjutnya aspek purpose in life (tujuan hidup) menekankan bahwa pentingnya individu memiliki tujuan hidup. Aspek ini juga terkait bagaimana individu dalam memaknai hidup serta menentukan arah dalam hidupnya (Prawoto, 2009). Hasil analisis di atas, item nomor 25 "Saya akan keluar dari bantuan yang diberikan oleh pemerintah" dan item pernyataan nomor 27 "Saya menabung untuk keperluan masa depan" merupakan item dengan kategori rendah yang mewakili aspek purpose in life (tujuan hidup). Berdasarkan item pernyataan nomor 25 , dapat diketahui bahwa sebagian keluarga miskin takut untuk keluar dari program pemerintah yang membuat keluarga tersebut tidak memiliki tujuan hidup yang dapat meningkatkan kondisi psikologis setiap anggota keluarga. Kemudian, dari item pernyataan nomor 27 , diketahui bahwa masih ada keluarga miskin yang tidak menyadari bahwa menabung untuk masa depan. Salah satu manfaatnya, dapat memabantu meningkatkan taraf ekonomi keluarga miskin tersebut. Hal ini berarti bahwa ketidakmampuan keluarga miskin untuk merencanakan tujuan hidup akan berdampak kepada psychological well-being setiap anggota keluarga (Takaredase, Kaawoan, \& Singkoh, 2019).

Salah satu item yang mewakili aspek Personal growth (pengembangan pribadi) adalah item pernyatan nomor 14 "Menyenangkan bagi saya untuk mengikuti kegiatan di program keluarga harapan karena bisa lepas dari rutinitas bekerja di rumah". Personal growth (pengembangan pribadi) merupakan kemampuan potensial yang dimiliki seseorang, perkembangan diri, serta keterbukaan terhadap pengalaman-pengalaman baru. Individu yang baik dalam dimensi ini memiliki perasaan untuk terus berkembang, melihat diri sendiri sebagai sesuatu yang terus tumbuh, menyadari potensi-potensi yang dimiliki dan mampu melihat peningkatan dalam diri dan tingkah laku dari waktu ke waktu (Homan, 2016). Hasil analisis data menunjukkan bahwa item pernyataan nomor 14 berada pada kategori rendah. Hal ini menunjukkan bahwa rendahnya kesadaran keluarga miskin akan pentingnya memiliki personal growth (pengembangan pribadi) untuk dapat memiliki kondisi psikologis yang tinggi. Karena dengan mengembangkan potensi yang dimiliki, maka kesejahteraan psikologis juga akan diperoleh (Ustama, 2009).

Autonomy (Kemandirian) adalah kemampuan yang dmiliki oleh individu untuk dapat mengendalikan dirinya sendiri, mandiri, independen, dan memiliki regulasi diri yang baik. Mampu untuk mengatur perilaku, dan dapat mengambil keputusan sendiri (Fadli et al., 2019). Hasil analisis data menunjukkan beberapa item yang mewakili aspek autonomy (kemandirian) berada pada kategori rendah. Diantarnya item pernyataan nomor 1 "Rasanya 
saya ingin memarahi orang yang menghina kondisi ekonomi saya" dan item pernyataan nomor 2 "Barang-barang yang saya beli sesuai dengan keinginan saya". Hal ini menandakan bahwa tingkat kemandirian yang dimiliki oleh keluarga miskin masih rendah. Sebagian dari keluarga miskin masih tidak mampu meregulasi diri serta mengendalikan dirinya untuk dapat hidup mandiri. Oleh karena itu autonomy (kemandirian) menjadi hal penting agar sebuah keluarga dapat memiliki psychological well-being yang tinggi (Hermawan, 2015; Mudjiran et al., 2017).

\section{Kesimpulan}

Berdasarkan penjelasan pada hasil dan pembahasan, dapat disimpulkan bahwa psychological well-being keluarga miskin Kota Padang sebagian besar berada pada kategori sedang, sebagian lagi berada pada kategori rendah dan ada yang berada pada kategori tinggi. Hal ini dibuktikan dengan nilai masing-masing aspek dari psychological well-being yang berada pada kategori sedang. Selanjutnya ada 10 item pernyataan berkategori rendah yang mewakili keenam aspek psychological well-being. Item yang rendah tersebut menjadi penyebab rendahnya psychological well-being sebagian besar keluarga miskin. Sehingga kualitas psychological well-being keluarga miskin kota padang sangat ditentukan oleh penerimaan diri terhadap kondisi yang dialami. Selain kurang mampu menerima kondisi yang dialami, keluarga miskin kurang mampu untuk tetap berpikir tenang sehingga mudah menyerah terhadap kemiskinan yang sedang terjadi. Hal lain yang menjadi faktor penyebab rendahnya psychological well-being adalah kurang mampu menjaga hubungan baik dengan sesama keluarga ataupun lingkungan masyarakat. Sering menjadikan kemiskinan sebagai alasan untuk bersifat individualis sehingga tidak peduli dengan lingkungan sekitar. Selanjutnya keluarga miskin juga kurang mampu beradaptasi terhadap lingkungan dalam bentuk pengembangan diri dengan tujuan untuk meningkatkan kesejahteraan psikologis keluarga.

Adapun hasil penelitian ini dapat digunakan atau dapat menjadi masukkan untuk pemerintah dalam meningkatkan psychological well-being keluarga miskin melalui Program Keluarga Harapan (PKH). Namun hal tersebut bisa membuat keluarga miskin untuk tidak mandiri. Sehingga diperlukan upaya lain berupa memberikan penyuluhan untuk meningkatkan psychological well-being keluarga miskin.

\section{Daftar Pustaka}

Badan Pusat Statistik. (2019). Angka Kemiskinan di Indonesia. Jakarta: Badan Pusat Statistik

Balzarotti, S., Biassoni, F., Villani, D., Prunas, A., \& Velotti, P. (2016). Individual Differences in Cognitive Emotion Regulation: Implications for Subjective and Psychological Well-Being. Journal of Happiness Studies, 17(1), 125-143. https://doi.org/10.1007/s10902-014-9587-3

Coley, R. L., Leventhal, T., Lynch, A. D., \& Kull, M. (2013). Relations between Housing Characteristics and the Well-Being of Low-Income Children and Adolescents. Dev Psychol, 49(9), 1775-1789. https://doi.org/10.1037/a0031033

Dogan, T., Totan, T., \& Sapmaz, F. (2013). The Role of Self-esteem, Psychological Wellbeing, Emotional Self-efficacy, And Affect Balance On Happiness: A Path Model. 
European Scientific Journal, 9(20), 31-42.

Fadli, R. P., Alizamar, A., Afdal, A., \& Ifdil, I. (2019). Psychological Well-Being of Youth Inventory on Domestic Violence Victims: Rasch Model Analysis. Journal of Couns$E d u, 4(2), 69-77$.

Hadjam, M. N. R., \& Nasiruddin, A. (2003). Peranan Kesulitan Ekonomi, Kepuasan Kerja dan Religiusitas terhadap Kesejahteraan Psikologis. Jurnal Psikologi, 2(2), 72-80.

Herien, P. (2012). Gender dan keluarga: Konsep realita di Indonesia. Bogor: IPB Press.

Hermawan, I. (2015). Analisis Eksistensi Sektor Pertanian terhadap Pengurangan Kemiskinan di Pedesaan dan Perkotaan. Mimbar, 28(2), 135-144.

Hidalgo, J. L. T., Bravo, B. N., Martínez, I. P., Pretel, F. A., Postigo, J. M., \& Rabadán, F. E. (2010). Psychological well-being, assessment tools and related factors (I. E. Wells, ed.). UK: Nova Science Publishers.

Homan, K. J. (2016). Self-Compassion and Psychological Well-Being in Older Adults. Journal of Adult Development, 23(2), 111-119. https://doi.org/10.1007/s10804-0169227-8

Irianto, A. (2010). Statistik Konsep Dasar, Aplikasi dan Pengembangan. Jakarta: Prenamedia Group.

Islamia, I., Sunarti, E., \& Hernawati, N. (2019). Tekanan Psikologis dan Kesejahteraan Subjektif Keluarga di Wilayah Perdesaan dan Perkotaan. Anfusina: Journal of Psychology, 2(1), 91-100.

Kuswardinah, A., Ansori, M., \& Rosidah, R. (2014). Model Pendidikan Kesejateraan Keluarga Bagi Keluarga Miskin di Pedesaan. Jurnal Penelitian Pendidikan, 31(2), 8592.

Maifizar, A. (2016). Karakteristik dan Fenomena Kemiskinan Keluarga Miskin Pedesaan di Aceh. Community, 2(3), 298-314. https://doi.org/10.4135/9781849209403.n73

Mudjiran, M., Hartati, N., \& Rinaldi, R. (2017). Optimalisasi Pengasuhan pada Keluarga Miskin dalam Rangka Meningkatkan Kesejahteraan Subyektif Anak di Kota Padang. Jurnal RAP UNP, 8(2), 158-169.

Noviawati, P., \& Narendri, N. I. (2017). Nilai-Nilai Kemiskinan pada Masyarakat Miskin di Daerah Perkotaan dan Pedesaan: Ditinjau berdasarkan Analisis Atribut Psikologis. Industrial Research Workshop and National Seminar, 265-273.

Noviawati, P., Nuzulia, S., Marlina, M., \& Undarwati, A. (2017). The Psychological Condition Differences Between the Rural and Urban Poor Society. Atlantis Press, 118, 103-106. https://doi.org/10.2991/icset-17.2017.18

Noviawati, P., \& Undarwati, A. (2017). Gambaran Dinamika Kemiskinan Ditinjau dari Atribut Psikologis: Studi Pada Masyarakat Miskin Kota Semarang. Seminar Nasional Multi Disiplin Ilmu \& Call For Papers Unisbank Ke-3. Unsibank.

Prawoto, N. (2009). Memahami Kemiskinan dan Strategi Penanggulangannya. Jurnal Ekonomi dan Studi Pembangunan, 9(1), 56-68. 
Qoyyimah, Q., \& Wahini, M. M. (2017). Faktor-Faktor Yang Memengaruhi Kesejahteraan Keluarga di Desa Pucanglaban Kecamatan Pucanglaban Kabupaten Tulungagung. EJurnal Tata Boga, 5(3), 63-72.

Raharjo, I. T., Puspitawati, H., \& Krisnatuti, D. (2015). Tekanan Ekonomi, Manajemen Keuangan, dan Kesejahteraan pada Keluarga Muda. Jur. Ilm. Kel. \& Kons., 8(1), 38-48.

Rochaida, E. (2016). Dampak Pertumbuhan Penduduk terhadap Pertumbuhan Ekonomi dan Keluarga Sejahtera di Provinsi Kalimantan Timur. Forum Ekonomi, 18(1), 14-24.

Ryff, C. D., \& Keyes, C. L. M. (1995). The Structure of Psychological Well-Being Revisited. Journal of Personality and Social Psychology, 6 (69), 719-727. https://doi.org/10.1037/ 0022-3514.69.4.719

Sagone, E., \& Caroli, M. E. De. (2014). Relationships between Psychological Well-being and Resilience in Middle and Late Adolescents. Procedia - Social and Behavioral Sciences, 141, 881-887. https://doi.org/10.1016/j.sbspro.2014.05.154

Smith, T. B., \& Silva, L. (2011). Ethnic Identity and Personal Well-Being of People of Color: A Meta-Analysis. Journal of Counseling Psychology, 58(1), 42-60. https://doi.org/10.1037/a0021528

Sudrajat, M., Sumpena, D., \& Azis, R. (2017). Peranan Tenaga Kesejahteraan Sosial dalam Meningkatkan Kesejahteraan Keluarga Miskin. Tamkin: Jurnal Pengembangan Masyarakat Islam, 2(2), 1-21.

Sugiharto, A., Hartoyo, H., \& Muflikhat, I. (2016). Strategi Nafkah dan Kesejahteraan Keluarga pada Keluarga Petani Tadah Hujan. Jur. Ilm. Kel. \& Kons, 9(1), 33-42.

Takaredase, J. T., Kaawoan, J. E., \& Singkoh, F. (2019). Program Keluarga Harapan dalam Pengentasan Kemiskinan di Kampung Manumpitaeng. Eksekutif, 3(3), 1-11.

Ustama, D. D. (2009). Peranan Pendidikan dalam Pengentasan Kemiskinan. Jurnal Ilmu Administrasi Dan Kebijakan Publik, 6(1), 1-12.

Ward, S. J., \& King, L. A. (2016). Poor but happy? Income, happiness, and experienced and expected meaning in life. Social Psychological and Personality Science, 7(5), 463-470. https://doi.org/10.1177/1948550615627865

Waters, T. E. A., \& Fivush, R. (2015). Relations Between Narrative Coherence, Identity, and Psychological Well-being in Emerging Adulthood. $J$ Pers, 83(4), 441-451. https://doi.org/10.1111/jopy.12120

Widyaningsih, E., \& Muflikhati, I. (2015). Alokasi Pengeluaran dan Kesejahteraan Keluarga pada Keluarga Nelayan Bagan. Jur. Ilm. Kel. \& Kons, 8(3), 182-192.

Yusuf, A. M. (2014). Metode Penelitian Kuantitatif, Kualitatif \& Penelitian Gabungan. Jakarta: Prenamedia Group. 